\title{
The Impacts of Lisbon Treaty on EU Trade Policy and EU-China Trade Relation
}

\author{
Ke Hong \\ School of Economics \\ Sichuan University \\ Chengdu, China
}

\begin{abstract}
The Lisbon Treaty is intended to make the EU more efficient, more democratic internally and more coherent on the world stage. There is no doubt that EU external trade policy is indeed affected by the Lisbon Treaty. And for EU-China trade relation, at this stage we can say that China will have to look more broadly to the EU's trade policy as an integral part of its overall external policy to the trading partners.
\end{abstract}

Keywords-The Lisbon Treaty; external trade policy; EUChina trade relation; mixed elements

\section{INTRODUCTION}

The European Union is the world's biggest trader, accounting for $20 \%$ of global imports and exports. Free trade among its members was one of the founding principles of the EU, and it is committed to liberalizing world trade for the benefit of rich and poor countries alike. Nowadays, Europe exports to every corner of the globe. [1]

Globalization is bringing more and more countries, rich and poor, into the world economy and subjecting them to increased competition. This process is changing how EU trade and how EU go about our everyday activities.

As we know, trade is not an objective in itself. It must be a tool to promote decent work in all its dimensions. Trade is not an objective in itself. It must be a tool to promote decent work in all its dimensions. Trade must be at the service of development and democracy, health and access to medicines, poverty eradication, protecting the environment, ensuring observance of human, democratic and trade union rights. These should all be underpinned by a fair trading system. [2]

Thus, the development of trade-if the trade could be properly managed, it would be an important opportunity for economic growth. The key is for the EU economy to be competitive and establish a set of internationally agreed rules.

The EU now has a single legal personality, which enables the EU as a whole to negotiate and sign in its name international treaties and agreements. To enhance the visibility of the EU and streamline the external representation of the EU, in international trade negotiations, the EU's 27 members are represented by the European Commission.

The EU trade policy has now to be seen as an integral part of overall EU external action and its relations with third countries, this implies that the EU in formulating its trade policy not only considers the economic liberalization agenda, but has to take into account other objectives. The Lisbon Treaty may therefore provide a basis for the use of conditionality in trade policy, and lead to the "politicization" of trade policy, something that may not be welcomed by EU's trading partners. [3]

\section{THE IMPACTS OF LISBON TREATY ON EU TRADE POLICY}

The Lisbon Treaty that was signed and ratified by all EU member states (MS) came into force on 1 December 2009. The Treaty is intended to make the EU more efficient, more democratic internally and more coherent on the world stage. It introduces a number of changes to the institutional structure and functioning which would also have an impact on EU trade policy.

\section{A. Clarification of EU Competence}

The Lisbon Treaty explicitly places the Common Commercial Policy under the exclusive competence of the Union (Article 3 of the Treaty of Lisbon) and extends the scope of the Common Commercial Policy to all key aspects of external trade. This clarifies the system of competences in the EU external trade policy area and simplifies the procedure for the adoption of far-reaching trade agreements between the EU and its partners. This would be in line with the new strategy defined in the "Global Europe" communication, which aims at reinforcing the role of the $\mathrm{EU}$ in the bi- and multilateral negotiation process of the new generation of free trade agreements and putting an end to the long disputed issue of the scope of the Common Commercial Policy. [4]

The Lisbon Treaty streamlines EU trade policy by confirming that all key aspects of external trade will henceforth come under exclusive EU competence. This dispenses with almost all of the mixed elements in trade agreements that have created confusion both within the EU and among the EU's trading partners. The treaty brings all services and trade related aspects of intellectual property (IP) into EU competence. This therefore concludes the long-standing debate on competence for these issues that began prior to the Maastricht intergovernmental conference (IGC) and continued through the Amsterdam (1996) and Nice (2001) IGCs and the Constitutional Convention. The inclusion of all services and trade-related aspects of IP in EU competence will not bring about any radical change however. Many services already fell 
under EC competence and the Commission has negotiated for the EC on all services and IP for many years. The change will be that a member state that is not content with what the Commission has negotiated will no longer have the formal right to seek unanimity. [5]

\section{B. An Increased Role for the European Parliament}

The formal position of the EP in EU external trade policy is enhanced in three main ways through the Lisbon Treaty. These concern the co-decision making powers with the Council for trade legislation, a greater say in negotiation and the power to grant its 'consent' to the adoption of all trade agreements negotiated by the EU. [5]

For the adoption of measures defining the framework for implementing the common commercial policy (CCP), the Lisbon Treaty establishes that all acts of legislative nature in the Common Commercial Policy will have to be adopted by the Ordinary Legislative Procedure, the former "co-decision procedure". This means that in the future, all legislation for implementing the CCP with the notable exception of international agreements will be co-decided by the Council and the EP. This includes for example all the regulations defining the EU trade defense instruments. [6]

What is more, where agreements with one or more third countries or international organizations need to be negotiated and concluded, the Lisbon Treaty establishes that:

"The Commission shall make recommendations to the Council, which shall authorise it to open the necessary negotiations. The Council and the Commission shall be responsible for ensuring that the agreements negotiated are compatible with internal Union policies and rules.

The Commission shall conduct these negotiations in consultation with a special committee appointed by the Council to assist the Commission in this task and within the framework of such directives as the Council may issue to it. The Commission shall report regularly to the special committee and to the European Parliament on the progress of negotiations." [7]

If it is still the Council that gives the Commission its negotiating mandate, the Commission is to report both to a committee appointed by the Council and to the European Parliament on the progress of negotiations. The Lisbon Treaty formalizes in that respect the current practice and gives it a legal basis.

Finally, the EP will have an enhanced role in ratifying trade agreements. Article 218 (6) (a) (i) to (v) sets out the criteria in which the consent16 of the EP, by a simple majority of MEPs, is required before the Council can adopt a decision concluding a trade agreement. [8] These are similar to the cases requiring EP assent before the Lisbon Treaty and include, association agreements, agreements establishing a specific institutional framework, and agreements with budgetary implications. A further criterion states that the EP's consent will be required for agreements covering fields to which OLP applies. As trade is now covered by the OLP this appears to make clear that the EP must give its consent before all trade agreements are adopted.

\section{Inclusion of Trade under the Common Heading of External Action by the EU}

A third area in which the Lisbon Treaty will bring about potential change is in the Article 205 (Part Five, External Action) provisions of the Lisbon Treaty that bring EU trade policy under the same EU external action heading as other elements of EU external policy. Trade policy is henceforth to be conducted within the 'context of the framework of principles and objectives of the EU's external action (Article 207(1)).

One of the main objectives of the Lisbon Treaty is to increase the coherence and the efficiency of the European Union's external action.

Thus, the Lisbon Treaty brings the current external Community policies together in a more comprehensive manner. All elements of the EU's external action from the common foreign and security policy to trade policy for example are from now on submitted to the same principles and objectives. These include inter alia human rights, good governance, environmental protection and sustainable development. [9]

\section{THE IMPACTS OF LISBON TREATY ON EU-CHINA TRADE RELATION}

The economic and trade relation between China and EU has the great significance to each party as well as to the world. As the great political and economic powers in the today's world, China and EU have the urgent motivations to promote the economic and trade cooperation between them at the global times. The economic relation between the EU and China has developed extraordinarily fast. Two decades ago, China and Europe traded almost nothing. Today, the EU is China's most important trading partner. Bilateral trade in goods alone nearly doubled over the last five years, reaching $€ 326$ bn. in 2008. [10]

Against the backdrop of the economic downturn, the EU and China met in order to push for more balanced trade, increased business opportunities and further economic cooperation.

\section{A. The Development of EU-China Trade Relation}

Initially EU-China links remained explicitly economic, though implicitly (certainly for China) strategic "Fig. 1". Their initial 1978 trade agreement was reaffirmed in the 1985 Agreement on Trade and Economic Cooperation, still the current framework, "to intensify and diversify their trade and actively develop economic and technical cooperation in line with their mutual interests" (EEC-China 1985). In economic terms, trade becomes a significant feature for both parties. Admittedly in the early 1980s there was some "stagnation in economic relations" as China reined in its economy; with Yahuda still terming the EC-China relationship a "secondary" one, in which "China ranks fairly low among EC trade partners" (Yahuda 1994: p.275). However trade patterns had changed dramatically several decades later. Total two-way trade increased over 30-fold since Deng Xiaoping's reforms began in China in 1978, for EU Trade Commissioner Lamy, the rate of growth "scarcely imaginable even a few years ago" (Lamy 2004).[11] 


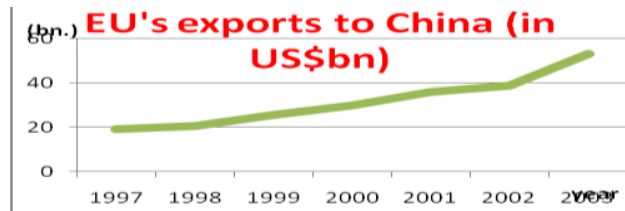

Fig. 1. EU's exports to China (in US\$bn). Source: Ting Wai, EU-China Relations: Economic, Political and Social Aspects (2004).

\section{B. The Current Situation of EU-China Trade Relation}

In 2010, China is the world's largest exporter, and the world's second largest national economy. China now accounts for about $11 \%$ of world trade in goods. Bilateral trade has gone from $€ 4$ billion in 1978 to $€ 296$ billion in 2009. The EU-China partnership builds on a solid and fast developing economic relationship.

The EU continues to be China's main export market. In 2009 the EU imported $€ 215$ billion worth of goods from China.

At the same time, China is Europe's fastest growing export market. The EU exported $€ 82$ billion worth of goods to China in 2009; up by $4 \%$ compared to 2008. Exports from the EU to China grew by approximately $€ 30$ billion between 2005 and 2009. EU exports up to China by the end of August 2010 were almost $40 \%$ up (year-on-year) amounting $€ 72,5$ billion. Still, the absolute level of EU exports remains below the potential that this relationship would justify "Table I".

TABLE I. THE EU IN WORLD TRADE 10 MAJOR EU EXPORT PARTNERS (2010)

\begin{tabular}{|c|c|c|c|}
\hline Rank. & EU Exports to & Mio Euro & \% world \\
\hline 1 & USA & 242.175 & 18,0 \\
\hline 2 & China & 113.106 & 8,4 \\
\hline 3 & Switzerland & 105.435 & 7,8 \\
\hline 4 & Russia & 86.577 & 6,4 \\
\hline 5 & Turkey & 61.206 & 4,5 \\
\hline 6 & Japan & 43.726 & 3,2 \\
\hline 7 & Norway & 41.756 & 3,1 \\
\hline 8 & India & 34.791 & 2,6 \\
\hline 9 & Brazil & 31.301 & 2,3 \\
\hline 10 & South Korea & 27.967 & 2,1 \\
\hline
\end{tabular}

European companies are deeply integrated in Asian and Chinese production chains. More than half of China's exports are currently produced by foreign invested enterprises (processing trade). Neighbouring Asian companies in Japan, Taiwan, Hong-Kong and South Korea play a major role in this process "Table II".

TABLE II. The EU IN World TRADE 10 MAJOR EU IMPORT PARTNERS (2010)

\begin{tabular}{|c|l|l|l|}
\hline Rank. & EU Imports from & Mio Euro & \% world \\
\hline $\boldsymbol{1}$ & China & 281.860 & $\mathbf{1 8 , 9}$ \\
\hline $\mathbf{2}$ & USA & 169.310 & $\mathbf{1 1 , 4}$ \\
\hline $\mathbf{3}$ & Russia & 154.899 & $\mathbf{1 0 , 4}$ \\
\hline $\mathbf{4}$ & Switzerland & 84.126 & 5,6 \\
\hline $\mathbf{5}$ & Norway & 78.997 & 5,3 \\
\hline $\boldsymbol{6}$ & Japan & 64.832 & $\mathbf{4 , 3}$ \\
\hline $\boldsymbol{7}$ & Turkey & 42.005 & 2,8 \\
\hline $\boldsymbol{8}$ & South Korea & 38.597 & 2,6 \\
\hline $\boldsymbol{9}$ & India & 32.987 & 2,2 \\
\hline $\mathbf{1 0}$ & Brazil & 32.272 & 2,2 \\
\hline
\end{tabular}

Source: European Commission, The European Union Trade Policy 2011
The EU runs a deficit with China on trade in goods which was $€ 133$ billion in 2009 (down from $€ 169$ billion in 2008). Through better market access, European exporters should be well placed to increasingly sell their quality products on the rapidly expanding Chinese consumer market. "Fig. 2", "Fig. 3"

\section{EU-ChinaTrade in Commercial Services}

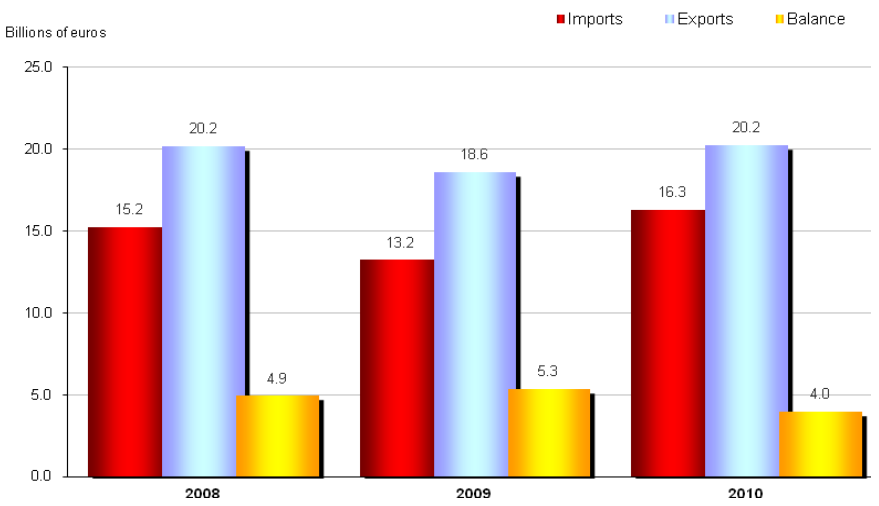

Fig. 2. EU-China trade in commercial services.

\section{EU-ChinaTrade in Goods}

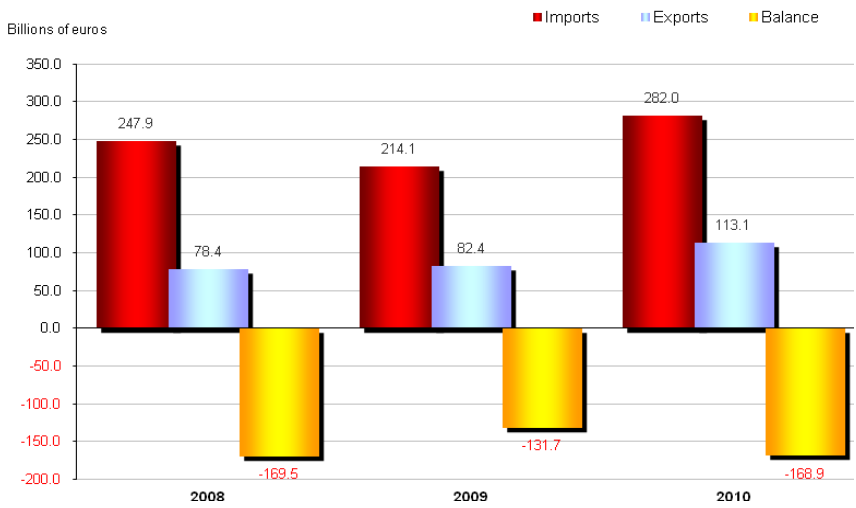

Fig. 3. EU-China trade in goods. Source: European Commission, trade Statistics, http://ec.europa.eu/trade/creating-opportunities/bilateralrelations/statistics/

Europe runs a surplus on trade in services with China of $€ 5.0$ billion in 2009 (up from $€ 4.9$ billion in 2008).

Also investment flows show vast untapped potential. European companies invested $€ 5.3$ billion in China in 2009 (up from $€ 4.7$ billion in 2008). China invested $€ 0.3$ billion in 2009 (compared to a net disinvestment of $€ 1.8$ billion in Europe in 2008). This is respectively less than $3 \%$ and $1 \%$ of both sides' total investment outflow. [12]

\section{The Impacts of Lisbon Treaty on EU-China Trade Relation}

Until the Lisbon treaty, "the EU had not taken full account of aims and principles outside the economics of trade policy". The new articles introduced in the Lisbon Treaty make clear that the EU not only has a liberalization agenda, but that other objectives - human rights, good governance, environmental 
protection, sustainable development - must be taken into account in formulating trade policy within the WTO as well as in the negotiation of bilateral trade and investment agreements. It also makes explicit what is already the case: that trade policy can be used in order to attain other non-economic objectives, and that links can be made between trade policy and the Union's principles and values. The Lisbon Treaty may therefore provide a basis for the use of conditionality in trade policy.

While trade agreements were sometimes used to pursue both economic and political objectives as in the case of the Europe Agreements with Central and Eastern European Countries in the mid-nineties, the decision to enter into a trade agreement with a third country outside of Europe has usually been motivated by economic reasons. In addition, as spelled out in the Global Europe strategy, "in the global economy, Europe's trade policy must become an integral part of its wider approach to economic reform and competitiveness". In particular, the strategy proposes a new program of bilateral free trade agreements with key partners in which economic - and not political - criteria are a primary consideration.

Furthermore, the enhanced role of the European Parliament (EP) in the trade policy will also increase the possibility of non-economic objectives such as human rights issues or environmental and social standards being taken into account. We have seen how the Lisbon Treaty enables the EP to play a full part in trade policy development and treaty-making.

In giving more powers to the EP, the Lisbon Treaty increases the democratic accountability of EU trade policy. This will also give more importance to the political dimension of any future trade negotiations as the EP is expected to exercise a more active and effective scrutiny of trade negotiations. This will need to be well taken into account by all acts involved as the EP is now to give its consent to all trade agreement on a "take it or leave it" basis.

The increased role of the European Parliament may lead to a "politicization" of the Common Commercial Policy and the use of conditionality in trade policy may be reinforced.

So for China, it must pay much more attention to the EU's whole external policies when it deals with the EU on trade issues. That means the future EU-China trade cooperation should include close coordination on energy, sustainable development, including environmental and social pillars and regulatory and sectoral policy issues, transportation, and cross cutting issues such as better regulation.

On the other hand, China should also watch more closely the EP when dealing with the EU on trade issues given the increased roles of the EP on trade policy. A lot will depend on the way the EP will exercise the new powers granted to it by the Lisbon Treaty.

\section{CONCLUSION}

Although it is not yet clear what the extent of the impact of reforms introduced by the Lisbon Treaty will be, and opinions diverge as to whether in practice the changes proposed by the Lisbon Treaty in relation to the EU's external trade agreements will significantly alter the status quo, there is no doubt that EU external trade policy is indeed affected by the Lisbon Treaty. An understanding of specific trade issues therefore requires an assessment of sector and vested interests and how they interact in the EU decision-making process in each specific case.

And for EU-China trade relation, at this stage we can say that China will have to look more broadly to the EU's trade policy as an integral part of its overall external policy to the trading partners. This may mean that non-trade policy issues will more easily interfere with specific trade agenda issues.

\section{REFERENCES}

[1] Policies of European Union, http://europa.eu/pol/comm/index_en.htm

[2] John Monks, The EU in world trade - Features of EU trade policy and current perspectives, Basis of remarks given by ETUC General Secretary John Monks at the Civil Society Dialogue Seminar on 26 March 2009

[3] Anne Pollet-Fort, Implications of the Lisbon Treaty on EU External Trade Policy. EU Centre, Singapore Background Brief No. 2, March 2010. EU Centre in Singapore

[4] Anne Pollet-Fort, Implications of The Lisbon Treaty for the European Union External Trade Policy (Common Commercial Policy) 2010, Eu Centre in Singapore.

[5] Stephen Woolcock, The Treaty of Lisbon and the European Union as an actor in international trade. 2010

[6] Article 207 TFEU, former Article 133 TEC

[7] Second meeting of the EU-China High Level Economic and Trade Dialogue: 7 and 8 May 2009 in Brussels, EUROPA press releases, http://europa.eu/rapid/pressReleasesAction.do?reference=MEMO/09/22 6

[8] Ting Wai, EU-China Relations: Economic, Political and Social Aspects (2004)

[9] David Scott, China-EU convergence 1957-2003: towards a 'strategic partnership', AEJ (2007) 5:217-233

[10] European Commission, The European Union Trade Policy 2011

[11] European Commission, trade Statistics, http://ec.europa.eu/trade/creating-opportunities/bilateralrelations/statistics/

[12] European Union, Third meeting of the EU-China High Level Economic and Trade Dialogue (HED) in Beijing 